\title{
Wave Matrix Technique for Waveguide Iris Polarizers Simulation. Theory
}

\author{
A.V. Bulashenko*, S.I. Piltyay ${ }^{\dagger}$ I.V. Demchenko ${ }^{\ddagger}$ \\ National Technical University of Ukraine "Igor Sikorsky Kyiv Polytechnic Institute”, 37, Peremohy Ave., \\ 03056 Kyiv, Ukraine
}

(Received 13 August 2020; revised manuscript received 15 December 2020; published online 25 December 2020)

\begin{abstract}
Today polarization-processing devices are widely used in satellite information systems. Waveguide polarizers are the key element of antenna systems used to convert signal polarization from linear to circular type and vice versa. The circularly polarized signals have many significant advantages over the signals with other types of polarization. Consequently, simultaneous application of polarizers with other radio signal processing devices highly increases the efficiency of new satellite information and telecommunication systems for various purposes, wireless data transmission systems, mobile communication systems, radar systems and medical diagnostic systems. In this article, we have developed a new matrix technique for the calculation of parameters and characteristics of a polarizer based on a square waveguide with three irises, which are inductive or capacitive loads depending on the wave's polarization. Based on the theory of microwave circuits, the analytical expressions of the general wave scattering matrix were derived using the transmission and scattering wave matrices of elements of a polarizer structure. As a result, the main characteristics of the polarizer were obtained: differential phase shift, voltage standing wave ratio for vertical and horizontal polarizations, axial ratio and cross-polar discrimination. The presented method makes it possible to study the influence of the polarizer dimensions, such as the heights of the irises and the distances between them, on its main characteristics. Obtained analytical model makes it possible to find theoretically optimal sizes, which provide the required polarization characteristics of the device with the best matching in the operating frequency band. In addition, the developed wave matrix technique can be applied for further optimization using the specialized programs for microwave device simulation.
\end{abstract}

Keywords: Scattering matrix, Transmission matrix, Polarizer, Waveguide polarizer, Iris polarizer, Circular polarization, Differential phase shift, Axial ratio, Cross-polar discrimination, Satellite antenna systems.

DOI: $10.21272 /$ jnep.12(6).06026

PACS numbers: 84.40.Az, 84.40.Ua

\section{INTRODUCTION}

Modern scientific publications describe many different methods for calculation of characteristics of waveguide microwave devices. For example, to obtain necessary polarization characteristics of waveguide iris and septum polarizers it is required to optimize the design [1-3] and calculate their differential phase shift with high accuracy.

Historically, the first techniques used to analyze phase shifters with reactive elements in waveguides were based on the scattering and transmission wave matrices $[4,5]$.

The vast majority of publications on waveguide devices is devoted to methods for calculation of microwave filters. In [6], the general approach to the synthesis of filters using the method of analytical gradient optimization is considered. The gradient function was determined analytically with respect to the change in the coupling elements between the resonators based on the theory of transmission and scattering matrices.

In [7], the procedure of microwave filters designing based on the model of distributed parameters is presented. The synthesis of an arbitrary frequency response, which is described by characteristic polynomials using scattering and transmission matrices, directly makes it possible to obtain the scattering parameters of various components that are realized by any gap that forms a filter. This method makes it possible to avoid the use of the numerical optimization process to determine the final configuration. In addition, the method gives the possibility to synthesize a frequency response, which compensates the effects of multimode interactions.

The general approach to the synthesis of coupling matrices is considered in [8], where a general method of synthesis with arbitrary reference impedances is suggested. Analytical expressions of scattering parameters and numerical results, that are in good agreement with the prototypes, were obtained. The approach converts the objective scattering matrix and reference impedances into an admittance matrix of multicoupled circuit based on the definition of power wave. In [9], the transmission matrix technique has been used to determine the filter parameters. Paper [10] presents the design of a symmetric response filter using Riblet's couplers. The reflection coefficients were calculated using Bartlett's theorem and the scattering matrix technique. The structure was implemented in $\mathrm{H}$-plane waveguide configuration for Ku-band applications.

In addition, the scattering matrix method is used to numerically verify the mode matching technique for the development of waveguide circuits [11]. The analysis of wave propagation in two-dimensional double corrugated metal surfaces embedded in a thin parallel plate waveguide is also based on the mode matching technique [12]. In [13], the hybrid surface integral-equation method for the analysis of waveguide components,

\footnotetext{
*an_bulashenko@i.ua

† crosspolar@ukr.net

†icegloom@gmail.com
} 
including resonator structures, was considered.

In [14], the waveguide duplexer model was calculated using the method of wave scattering and transmission matrices. The suggested design uses duplex transmission based on the reception and transmission of signals with orthogonal circular polarizations. The formation of circular polarization is carried out by partitioning the converter of the polarizer orthogonal modes in the waveguide. In [15-17], the techniques of analysis of waveguide polarizers based on reactive elements are considered.

In [18], the electrodynamic problem of finding a generalized scattering matrix of an infinitely thin asymmetric one-sided inductive diaphragm in a rectangular waveguide was solved using the method of integrated levels.

Despite the large number of works devoted to different numerical methods for the calculation of characteristics of phase shifters and microwave filters, the wave matrix techniques were not used to calculate the characteristics of waveguide polarizers. Therefore, in this article, we develop a mathematical model of a square waveguide polarizer based on scattering and transmission wave matrices. Obtained model allows to simulate main polarization and matching characteristics in future research of iris polarizers. In addition, the optimization of waveguide polarizers can be carried out using the developed wave matrices technique.

\section{WAVE MATRIX ANALYSIS OF WAVEGUIDE IRIS POLARIZERS}

Using the analysis of microwave devices based on the theory of wave scattering and transmission matrices [19], we develop a mathematical model of a rectangular or square waveguide loaded by irises. The obtained model can have equivalent reactances of two types. Such a design can perform the functions of a polarizer or phase shifter. The electromagnetic characteristics of the device, which are calculated using the model, are the differential phase shift, axial ratio, voltage standing wave ratio (VSWR) and cross-polar discrimination (XPD).

As an example of the theoretical analysis, we will consider a polarizer based on a square waveguide with 3 irises (Fig. 1). Designations of all sizes of the design are presented in Fig. 1. The size of the square waveguide's walls is a. Two outer irises have the same heights $h_{1}$. In order to improve matching of the polarizer, the outer irises are lower than the central iris with the height $h_{2}$. The thicknesses of all irises are infinitely small and the distances between them are equal to $l$.
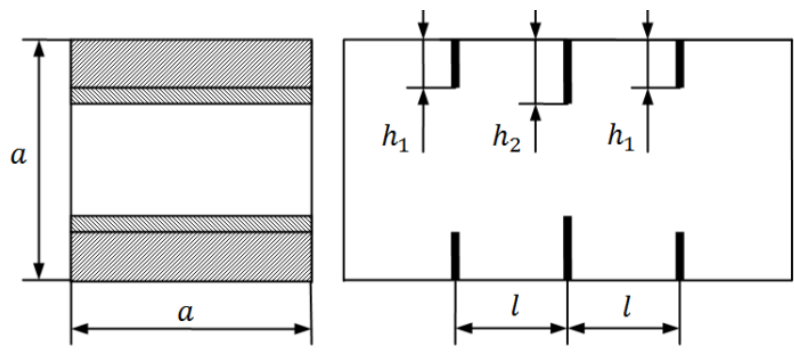

Fig. 1 - The design of a waveguide polarizer with 3 irises
The reactive elements in a waveguide are conductive irises (Fig. 2), which can be represented as reactive elements connected in parallel into the equivalent transmission line. Their normalized reactive conductivities are determined by the following formulae:

$$
\begin{gathered}
b_{L} \cong \frac{\lambda_{g}}{a} \cdot\left[\operatorname{ctg}\left(\frac{\pi \cdot d}{2 a}\right)\right]^{2}, \\
b_{C} \cong \frac{4 b}{\lambda_{g}} \cdot \ln \left[\operatorname{cosec}\left(\frac{\pi \cdot d}{2 a}\right)\right],
\end{gathered}
$$

where $a$ and $b$ are the lengths of the wide and narrow walls of the rectangular waveguide, respectively; $d$ is the width of the iris window; $\lambda_{g}$ is the guide wavelength. In the case of a square waveguide $a=b$.

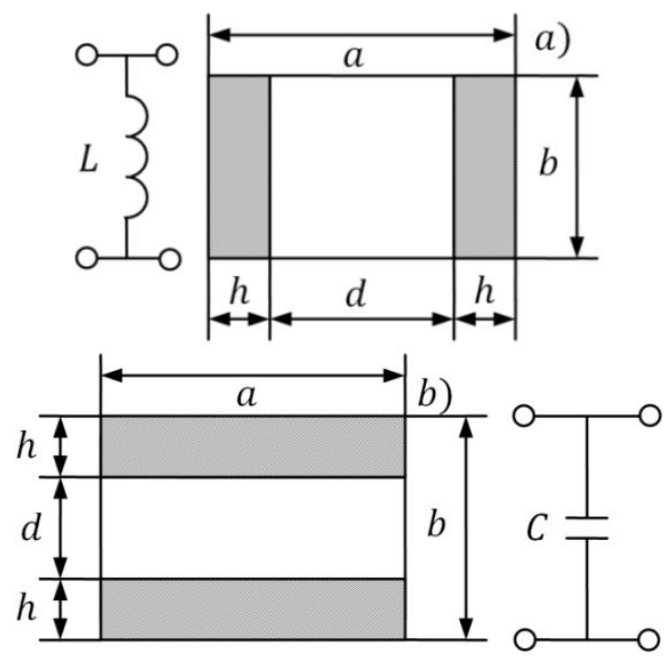

Fig. 2 - Inductive and capacitive irises in a waveguide

The width $d$ of the iris window and its height $h$ are connected by the following formula:

$$
d=a-2 \cdot h .
$$

The guide wavelength in a square waveguide is determined by the expression [19]:

$$
\lambda_{g}=\frac{\lambda}{\sqrt{1-\left(\frac{\lambda}{\lambda_{C}}\right)^{2}}},
$$

where $\lambda=c / f$ is the wavelength in free space, $\lambda_{C}=2 a$ is the cutoff wavelength for the fundamental $\mathrm{TE}_{10}$ mode in a waveguide.

For the analysis of a polarizer, we apply a singlewave approximation using the apparatus of wave matrix theory. The general view of an equivalent circuit of a waveguide with 3 reactive irises is shown in Fig. 3.

For the determination of the general wave matrix of the reduced two-port circuit (Fig. 3), we divide it into 5 simple two-port circuits. There are 3 two-port circuits in the form of reactive discontinuity and 2 two-port circuits in the form of a regular segment of the transmission line with characteristic impedance $\rho$ and electric length $\theta$, which is determined as follows: 


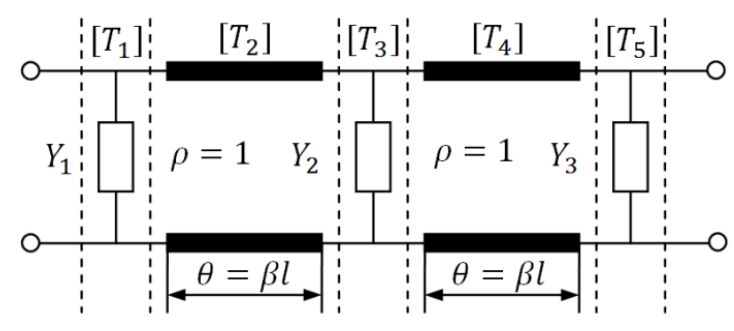

Fig. 3 - Equivalent circuit of a waveguide with 3 irises

$$
\theta=\frac{2 \pi}{\beta}=\frac{2 \pi \cdot l}{\lambda_{g}}
$$

where $l$ is the length of the gap between irises.

The distance between irises can be approximately estimated as a quarter of the guide wavelength at the central frequency:

$$
l \approx \frac{\lambda_{g}}{4} .
$$

All calculations will be carried out in the matched mode at the input/output ports, for which the normalized characteristic impedance $\rho=1$. Each two-port circuit is described by a wave transmission matrix:

$$
\begin{aligned}
& {\left[T_{1}\right]=\left[T_{5}\right]=\left[\begin{array}{ll}
T_{11} & T_{12} \\
T_{21} & T_{22}
\end{array}\right] ; \quad\left[T_{3}\right]=\left[\begin{array}{cc}
T_{11}^{\prime} & T_{12}^{\prime} \\
T_{21}^{\prime} & T_{22}^{\prime}
\end{array}\right] ;} \\
& {\left[T_{2}\right]=\left[T_{4}\right]=\left[\begin{array}{cc}
e^{j \theta} & 0 \\
0 & e^{-j \theta}
\end{array}\right]}
\end{aligned}
$$

Then the complete wave transmission matrix of the polarizer is determined as the product of all 5 matrices:

$$
\left[T_{\Sigma}\right]=\left[T_{1}\right] \cdot\left[T_{2}\right] \cdot\left[T_{3}\right] \cdot\left[T_{4}\right] \cdot\left[T_{5}\right]=\left[\begin{array}{ll}
T_{\Sigma 11} & T_{\Sigma 12} \\
T_{\Sigma 21} & T_{\Sigma 22}
\end{array}\right],
$$

where

$$
\begin{aligned}
& T_{\Sigma 11}=T_{11}^{2} T_{11}^{\prime} e^{j 2 \theta}+T_{11} T_{12} T_{21}^{\prime}+T_{11} T_{21} T_{12}^{\prime}+T_{12} T_{21} T_{22}^{\prime} e^{-j 2 \theta} \\
& T_{\Sigma 12}=T_{11} T_{12} T_{11}^{\prime} e^{j 2 \theta}+T_{12}^{2} T_{21}^{\prime}+T_{11} T_{22} T_{12}^{\prime}+T_{12} T_{22} T_{22}^{\prime} e^{-j 2 \theta}, \\
& T_{\Sigma 21}=T_{11} T_{21} T_{11}^{\prime} e^{j 2 \theta}+T_{11} T_{22} T_{21}^{\prime}+T_{21}^{2} T_{12}^{\prime}+T_{21} T_{22} T_{22}^{\prime} e^{-j 2 \theta}, \\
& T_{\Sigma 22}=T_{12} T_{21} T_{11}^{\prime} e^{j 2 \theta}+T_{12} T_{22} T_{21}^{\prime}+T_{21} T_{22} T_{12}^{\prime}+T_{22}^{2} T_{22}^{\prime} e^{-j 2 \theta}
\end{aligned}
$$

The relationship between wave transmission and scattering matrices is as follows:

$$
\left[S_{\Sigma}\right]=\left[\begin{array}{ll}
S_{\Sigma 11} & S_{\Sigma 12} \\
S_{\Sigma 21} & S_{\Sigma 22}
\end{array}\right]=\frac{1}{T_{\Sigma 11}}\left[\begin{array}{cc}
T_{\Sigma 21} & |T| \\
1 & -T_{\Sigma 12}
\end{array}\right]
$$

where $|T|$ is the determinant of the matrix $\left[T_{\Sigma}\right]$ from formula (8).

Having used the property of a symmetrical two-port circuit $S_{\Sigma 11}=S_{\Sigma 22}$ and $S_{\Sigma 12}=S_{\Sigma 21}$, we obtain

$$
\begin{gathered}
S_{\Sigma 21}=\frac{1}{\mathrm{~T}_{\Sigma 11}}=\frac{S_{21}^{2} \cdot S_{21}^{\prime}}{e^{j 2 \theta}-2 S_{11} S_{11}^{\prime}+S_{11}^{2} K e^{-j 2 \theta}} \\
S_{\Sigma 11}=\frac{\mathrm{T}_{\Sigma 21}}{\mathrm{~T}_{\Sigma 11}}=\frac{S_{11} e^{j 2 \theta}-S_{11}^{\prime} N-S_{22}^{\prime} S_{11}^{2}+S_{11} P e^{-j 2 \theta}}{e^{j 2 \theta}-2 S_{11} S_{11}^{\prime}+S_{11}^{2} K e^{-j 2 \theta}}
\end{gathered}
$$

where $N=S_{11}^{2}-S_{21}^{2} ; K=S_{11}^{\prime 2}-S_{21}^{\prime 2} ; P=N \cdot\left[S_{11}^{\prime 2}-S_{21}^{\prime 2}\right]$.

The analytical model of a waveguide with 3 inductive irises is shown in Fig. 4. In this case, the elements of a scattering matrix are as follows:

$$
S_{11}=\frac{j b_{L}}{2-j b_{L}}, \quad S_{21}=\frac{2}{2-j b_{L}} .
$$

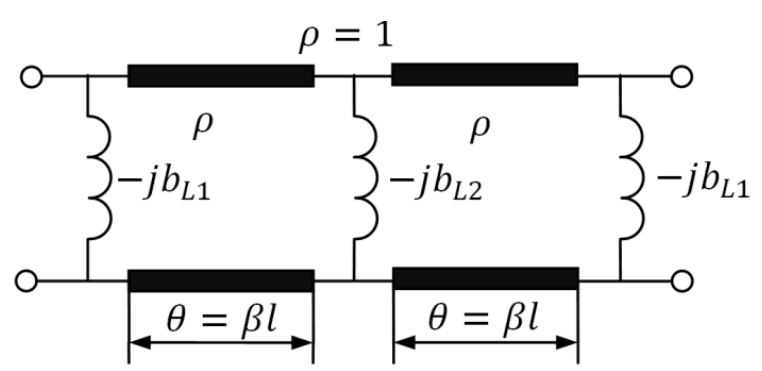

Fig. 4 - Equivalent circuit of a waveguide with 3 inductive irises

In Fig. 4, the two outer inductances are equal and the middle inductance is higher in order to achieve simultaneously the required phase characteristic and matching over a wide operating frequency range.

In formula (12) we denote by $S_{11 L}$ and $S_{21 L}$ the elements of the scattering matrix for the two outer inductive irises. $S_{11 L}^{\prime}$ and $S_{21 L}^{\prime}$ stand for the elements of the scattering matrix of the middle inductive irises.

Having substituted expressions (12) into (10) and (11), we obtain the following formulae:

$$
\begin{gathered}
S_{\Sigma 21 L}=\frac{S_{21 L}^{2} \cdot S_{21 L}^{\prime}}{e^{j 2 \theta}-2 S_{11 L} S_{11 L}^{\prime}+S_{11 L}^{2} K e^{-j 2 \theta}} ; \\
S_{\Sigma 11 L}=\frac{S_{11 L} e^{j 2 \theta}-S_{11 L}^{\prime} N-S_{22 L}^{\prime} S_{11 L}^{2}+S_{11 L} P e^{-j 2 \theta}}{e^{j 2 \theta}-2 S_{11 L} S_{11 L}^{\prime}+S_{11 L}^{2}\left(S_{11 L}^{\prime 2}-S_{21 L}^{\prime 2}\right) e^{-j 2 \theta}}
\end{gathered}
$$

where $N=S_{11 L}^{2}-S_{21 L}^{2}, K=S_{11 L}^{\prime 2}-S_{21 L}^{\prime 2}$,

$$
P=N \cdot\left[S_{11 L}^{\prime 2}-S_{21 L}^{\prime 2}\right] \text {. }
$$

The equivalent circuit of a waveguide with 3 capacitive irises is shown in Fig. 5. In this circuit, the elements of a scattering matrix are as follows:

$$
S_{11}=\frac{-j b_{C}}{2+j b_{C}}, \quad S_{21}=\frac{2}{2+j b_{C}} .
$$

In the equivalent circuit shown in Fig. 4 the two outer capacitances are equal and the middle capacitance is higher in order to achieve simultaneously the required phase characteristic and matching over a wide operating frequency range. 


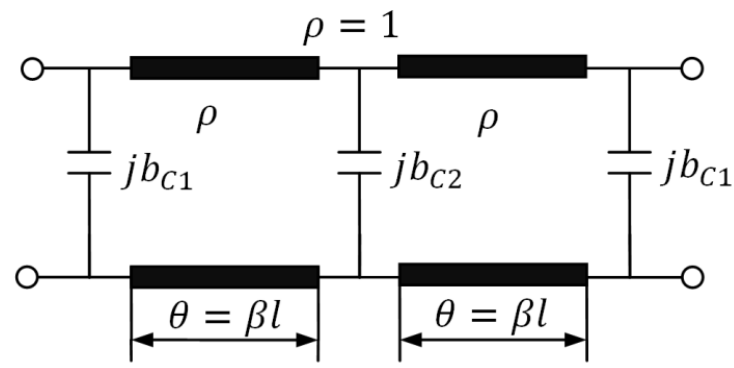

Fig. 5 - Equivalent circuit of a waveguide with 3 capacitive irises

In expression (15), $S_{11 C}$ and $S_{21 C}$ stand for the elements of the scattering matrix for the two outer capacitances. $S_{11 C}^{\prime}$ and $S_{21 C}^{\prime}$ designate the elements of the scattering matrix of the middle capacitance.

After substituting expressions (15) into (10) and (11), we obtain analytical expressions

$$
\begin{gathered}
S_{\Sigma 21 \mathrm{C}}=\frac{S_{21 C}^{2} \cdot S_{21 C}^{\prime}}{e^{j 2 \theta}-2 S_{11 C} S_{11 C}^{\prime}+S_{11 C}^{2} K e^{-j 2 \theta}}, \\
S_{\Sigma 11 \mathrm{C}}=\frac{S_{11 C} e^{j 2 \theta}-S_{11 C}^{\prime} N-S_{22 C}^{\prime} S_{11 C}^{2}+S_{11 C} P e^{-j 2 \theta}}{e^{j 2 \theta}-2 S_{11 C} S_{11 C}^{\prime}+S_{11 C}^{2} K e^{-j 2 \theta}},
\end{gathered}
$$

where $N=S_{11 C}^{2}-S_{21 C}^{2} ; K=S_{11 C}^{\prime 2}-S_{21 C}^{\prime 2}$;

$$
P=N \cdot\left[S_{11 C}^{\prime 2}-S_{21 C}^{\prime 2}\right] \text {. }
$$

Therefore, we have obtained the complete scattering matrices of the polarizer for the fundamental modes $\mathrm{TE}_{10}$ and $\mathrm{TE}_{01}$ with orthogonal linear polarizations.

\section{ANALYTICAL FORMULAE FOR THE CHARACTERISTICS OF WAVEGUIDE IRIS POLARIZERS}

The main electromagnetic characteristics of a polarizer are peak levels of voltage standing wave ratio (VSWR) for both linear polarizations, differential phase shift, axial ration and cross-polar discrimination (XPD).

The differential phase shift at the output of a polarizer is determined as the difference between the arguments of complex transmission coefficients for two orthogonal linear polarizations. Using the equivalent circuits (Fig. 4, Fig. 5) of a waveguide polarizer for the fundamental modes of two polarizations, we can express the differential phase shift as follows:

$$
\Delta \phi=\phi_{\mathrm{L}}-\phi_{\mathrm{C}}=\arg \left(S_{\Sigma 21 L}\right)-\arg \left(S_{\Sigma 21 C}\right) .
$$

The matching of a microwave device is characterized by VSWR [19]. For the equivalent circuits with inductive and capacitive irises, VSWR is calculated using the following formulae:

$$
\begin{aligned}
& V S W R_{L}=\frac{1+\left|S_{\Sigma 11 L}\right|}{1-\left|S_{\Sigma 11 L}\right|} ; \\
& V S W R_{C}=\frac{1+\left|S_{\Sigma 11 C}\right|}{1-\left|S_{\Sigma 11 C}\right|} .
\end{aligned}
$$

The circular polarization purity at the output of a polarizer is characterized by the axial ratio. It is usually expressed in $\mathrm{dB}$. In the linear polarization basis, the axial ratio is determined as follows [20]:

$$
r[\mathrm{~dB}]=10 \lg \frac{A^{2}+B^{2}+\sqrt{A^{4}+B^{4}+2 A^{2} B^{2} \cos (2 \Delta \phi)}}{A^{2}+B^{2}-\sqrt{A^{4}+B^{4}+2 A^{2} B^{2} \cos (2 \Delta \phi)}}
$$

where $A=\left|S_{\sum 21 \mathrm{~L}}\right|, B=\left|S_{\sum 21 \mathrm{C}}\right|, \Delta \phi$ is defined in (18).

$\mathrm{XPD}$ is the equivalent characteristic of the polarization purity of the electromagnetic wave at the output of a polarizer. Usually it is also expressed in $\mathrm{dB}$ and can be determined using formula (21) as follows:

$$
\mathrm{XPD}[\mathrm{dB}]=20 \lg \left(\frac{r+1}{r-1}\right),
$$

where $r$ is the axial ratio, which preliminary must be transformed to a linear scale from the logarithmic one.

Axial ratio (21) and XPD (22) at the polarizer's output along with the differential phase shift (18) and VSWRs (19), (20) for the electromagnetic waves of both polarizations must be simultaneously calculated during the simulation of iris polarizers. Developed analytical technique can be used for the optimization of waveguide iris polarizers for different fractional bandwidths.

\section{CONCLUSIONS}

A new wave matrix technique has been developed for the theoretical analysis of waveguide iris polarizers. The irises were simulated as inductive or capacitive reactive elements depending on the polarization type of the fundamental electromagnetic mode in the waveguide.

The main principles of the suggested approach have been demonstrated by the example of a square waveguide polarizer with 3 irises. The formulae for the calculation of all elements of the transmission and scattering wave matrices have been obtained. Based on the scattering matrix elements we can calculate all electromagnetic characteristics of the polarizer including differential phase shift, VSWR for the fundamental modes of both polarizations, axial ratio and XPD.

The formulae for the calculation of axial ratio and XPD, which simultaneously take into account the differential phase shift and magnitudes of fundamental modes with orthogonal linear polarizations at the output of the polarizer, have been presented in the article.

Obtained in the research formulae allow to analyze theoretically the dependence of polarizer characteristics on the variation of the heights of the irises and the distances between them. Such results are important for fast development and optimization of the waveguide iris polarizers. In addition, obtained in the research analytical dependences can be widely applied for the sensitivity analysis of the polarizer characteristics.

Therefore, the developed theoretical wave matrix technique can be recommended for the development of practical designs of iris polarizers and other waveguide microwave devices. In the future research we will apply the wave matrix technique for optimization of a compact square waveguide polarizer with 3 irises and comparison of obtained characteristics with those calculated using numerical techniques. 


\section{REFERENCES}

1. G. Virone, R. Tascone, O.A. Peverini, G. Addamo, R. Orta IEEE Microw. Wirel. Co. 18 No 8, 509 (2008).

2. J. Fligare, M. Pantaleev, IEEE T. Antenn. Propag. Co. 68 No 1, 207 (2020).

3. F.F. Dubrovka, S.I. Piltyay, R.R. Dubrovka, M.M. Lytvyn, S.M. Lytvyn, Radioelectron. Commun. Syst. 63 No 1, 15 (2020).

4. Y. Leviatan, P.G. Li, A.T. Adams, J. Perini, IEEE T. Microw. Theory 31 No 10, 806 (1983).

5. S.Y. Zheng, W.S. Chan, K.F. Man, IEEE Microw. Wirel. Co. 20 No 9, 498 (2010).

6. S. Amari, IEEE T. Microw. Theory. 48 No 9, 1559 (2000).

7. R. Tascone, P. Savi, D. Trinchenko, R. Orta, IEEE T. Microw. Theory. 48 No 3, 423 (2000).

8. C. Ge, X.-W. Zhu, X. Jiang, X.-J. Xu, IEEE Microw. Wirel. Co. 25 No 6, 349 (2015)

9. J.R. Montejo-Garai, J.A. Ruiz-Crus, J.M. Rebollar, M.J. Padilla-Cruz, A. Onoro-Navarro, I. HidalgoCarpintero, IEEE T. Microw. Theory. 53 No 5, 1636 (2005).

10. J.R. Montejo-Garai, C.A. Leal-Sevillano, J.A. Ruiz-Crus, J.M. Rebollar, International Conference on Electromagnetics in Advanced Applications (ICEAA), art. No. 6328627 (Cape Town: IEEE: 2012).

11. G.V. Eleftheriades, A.S. Omar, L.P.B. Katehi, G.M.Rebeiz,
IEEE T. Microw. Theory. 42 No 10, 1896 (1994).

12. F. Ghasemifard, M. Norgren, O. Quevedo-Teruel, IEEE Microw. Wirel. Co. 28 No 1, 1 (2018).

13. V. Catina, F. Arndt, J. Brandt, IEEE T. Microw. Theory. 53 No 11, 3562 (2005)

14. C.A. Leal-Sevillano, K.B. Cooper, J.A. Ruiz-Cruz, J.R. Montejo-Garai, J.M. Rebollar, IEEE T. Microw. Theory. 3 No 5, 574 (2013).

15. F.F. Dubrovka, S.I. Piltyay, XI IEEE International Conference on Antenna Theory and Techniques (ICATT), art. No 7972642, 277 (Kyiv: IEEE: 2017)

16. S.I. Piltyay, XI IEEE International Conference on Antenna Theory and Techniques (ICATT), art. No 7972644, 284 (Kyiv: IEEE: 2017).

17. F.F. Dubrovka, S.I. Piltyay, IX IEEE International Conference on Antenna Theory and Techniques (ICATT), art. No 6650816, 473 (Odesa: IEEE: 2013).

18. O.S. Zakharchenko, S.Ye. Martynyuk, P.Ya. Stepanenko, Visnyk NTUU KPI Seria Radiotekhnika Radioaparatobuduvannia. 72 No 1, 13 (2018).

19. D.M. Pozar, Microwave Engineering (Hoboken, New Jersey: John Wiley \& Sons: 2012).

20. J.A. Ruiz-Cruz, M.M. Fahmi, S.A. Fouladi, R.R. Mansour, IEEE T. Microw. Theory. 59 No 12, 3365 (2011).

\title{
Метод хвильових матриць для моделювання хвилеводних поляризаторів із діафрагмами. Теорія
}

\author{
А.В. Булашенко, С.І. Пільтяй, І.В. Демченко
}

\section{Національний технічний університет Украйни "Київський політехнічний інститут імені Ігоря Сікорського", пр. Перемоги, 37, 03056 Київ, Украӥна}

\begin{abstract}
Сьогодні пристрої оброблення поляризації широко використовуються у супутникових інформаційних системах. Хвилеводні поляризатори є ключовим елементом антенних систем, що використовуються для перетворення поляризації сигналу із лінійної в колову та навпаки. Сигнали із коловою поляризацією мають багато значних переваг над сигналами з іншими видами поляризації. Таким чином, одночасне використання поляризаторів з іншими радіотехнічними пристроями обробки сигналів значно підвищуе ефективність нових супутникових інформаційних і телекомунікаційних систем різного призначення, бездротових систем передачі даних, мобільних систем зв'язку, радіолокаційних систем та систем медичної діагностики. В статті розроблено новий матричний метод розрахунку параметрів та характеристик поляризатора на основі квадратного хвилеводу із трьома діафрагмами, які $е$ індуктивними чи емнісними залежно від поляризації хвилі. Використовуючи теорію мікрохвильових кіл, через хвильові матриці передачі та розсіювання елементів структури поляризатора було виведено аналітичні вирази для загальної хвильової матриці розсіювання. У результаті було отримано основні характеристики поляризатора: диференційний фазовий зсув, коефіціент стійної хвилі за напругою для вертикальної та горизонтальної поляризації, коефіціент еліптичності та кросполяризаційна розв'язка. Представлений метод дозволяе дослідити вплив розмірів поляризатора (а саме, висот діафрагм та відстаней між ними) на його основні характеристики. Отримана аналітична модель дозволяе теоретично знаходити оптимальні розміри, які забезпечують необхідні поляризаційні характеристики пристрою при найкращому узгодженні в робочому діапазоні частот. Крім цього, розроблений метод хвильових матриць може застосовуватися для подальшої оптимізації за допомогою спеціалізованих програм моделювання мікрохвильових пристроїв,
\end{abstract}

Ключові слова: Матриця розсіювання, Матриця передачі, Поляризатор, Хвилеводний поляризатор, Поляризатор із діафрагмами, Колова поляризація, Диференційний фазовий зсув, Коефріщієнт еліптичності, Кросполяризаційна розв’язка, Супутникові антенні системи. 